\title{
On the genus Hamma Buckton, 1905 (Hemiptera: Auchenorrhyncha) in Equatorial Africa, with descriptions of three new species
}

\author{
Antonio DURANTE ${ }^{1, *}$, Sandrine Mariella BAYENDI LOUDIT ${ }^{2} \&$ Antonio SUSINI $^{3}$ \\ ${ }^{1}$ Museo di Storia naturale del Salento, S.P. Calimera-Borgagne, Km 1, 73021 Calimera, Lecce, Italy. \\ ${ }^{2}$ Institut de Recherches Agronomiques et Forestières, BP 13 260, Libreville, Gabon. \\ ${ }^{3}$ Corso Porta Ticinese, 42. 20123, Milano, Italy. \\ *Corresponding author: antonio.durante@msns.it \\ 2Email: sbayendiloudit@gmail.com \\ ${ }^{3}$ Email: antoniosusini@hotmail.it \\ ${ }^{1}$ urn:lsid:zoobank.org:author:EE002752-B8CA-40FA-A6B2-02B46375D850 \\ ${ }^{2}$ urn:1sid:zoobank.org:author:DB43D625-BCF2-40B5-846A-C34B077754A8 \\ ${ }^{3}$ urn:lsid:zoobank.org:author:BA4917CF-EE9E-4CC2-B441-82C2019D7052
}

\begin{abstract}
As part of the classification of Membracidae from Gabon and Equatorial Guinea, a new species group of the genus Hamma Buckton, 1905 is proposed, and three new species are described: Hamma nigrum sp. nov., Hamma spinellii sp. nov. and Hamma caneparii sp. nov. An updated checklist and key to the genus Hamma are provided.
\end{abstract}

Keywords. Membracidae, Hamma, new taxa, Gabon, Equatorial Guinea.

Durante A., Bayendi Loudit S.M. \& Susini A. 2021. On the genus Hamma Buckton, 1905 (Hemiptera: Auchenorrhyncha) in Equatorial Africa, with descriptions of three new species. European Journal of Taxonomy 748: 89-107. https://doi.org/10.5852/ejt.2021.748.1345

\section{Introduction}

As already stated by Bayendi Loudit et al. (2014), new species in the genus Hamma Buckton, 1905 will probably continue to be found for many years. The present study is the third on the family Membracidae Rafinesque, 1815, specifically dealing with the genus Hamma in Gabon.

Gabon represents one of the most well-conserved natural areas in Sub-Saharan Africa and a sanctuary for equatorial forests. Its wildlife conservation policy is encouraging and promotes research and conservation. The MSNS (Museo di Storia naturale del Salento, Italy) pursues a research strategy in agreement with the local authorities to provide the necessary tools for wildlife preservation.

In the present paper we follow Capener (1968) and Wallace \& Deitz (2004) in placing the genus Hamma in the tribe Centrotini Amyot \& Serville, 1843. Previous studies of Centrotinae Amyot \& Serville, 1843 in Africa and the genus Hamma in particular are summarized in the works of Stål (1866), Goding (1932), Capener (1968, 1972), Boulard (1968, 1969), Bayendi Loudit et al. (2014) and Durante \& 
Susini (2017). The overall classification of the African Centrotinae is also summarized in the works of Funkhouser (1950), Metcalf \& Wade (1965) and McKamey (1998), as noted by Wallace \& Deitz (2004), who published the most recent genus-level revision of the subfamily.

In their recent paper on the genus Hamma (Durante \& Susini 2017), the current authors raised the number of species in the genus to 19 in Africa as a whole and 9 in Gabon alone. Thanks to new research, they discovered new material which appears to belong to three new species.

The objective of the zoological studies of the MSNS on the Membracidae includes examination of hundreds of specimens collected in Gabon from 2010 until 2019, with subsequent publication of the relevant results. Unfortunately, it will remain a long-term objective as the financial resources of the MSNS are very sparse and are mainly based on private generosity.

\section{Material and methods}

The examined material is part of the MSNS and Antonio Susini's private collections. The collections of the RMCA (Royal Museum for Central Africa, Tervuren, Belgium) and MNHN (Muséum national d'histoire naturelle, Paris, France) were also checked.

The specimens were collected in Batouala in Ogooué Ivindo Province, Gabon, close to Mount Sassamongo at about $660 \mathrm{~m}$ above sea level; in Inzambò (a small village on Mount Iboundji at $427 \mathrm{~m}$ above sea level) in Ogooué Lolo Province, Gabon, during a survey in 2012; and in Mossumu in Equatorial Guinea in 2015.

Collection was conducted at night, using a 500-watt blended light lamp suspended in front of a white cotton sheet against a wall, collecting actively from $7 \mathrm{pm}$ to about midnight and irregularly until sunrise.

According to the literature (Funkhouser 1950; Capener 1962), treehoppers should usually be collected during the daytime. However, subsequent studies (Kopp \& Yonke 1973) demonstrated that Centrotinae are attracted to light, albeit unreliably in terms of quantity. There are well-documented occurrences of massive collection of Membracidae that are attracted to light at night (including other genera not yet studied; see also Bayendi Loudit et al. 2014).

Some specimens were killed using ethyl acetate vapours and dried for storage; they were briefly dipped in warm water (for about $30 \mathrm{sec}$ at $60^{\circ}-70^{\circ} \mathrm{C}$ ) prior to study. Other specimens, after killing in ethyl acetate, were stored in $70 \%$ ethanol; they needed no wetting procedure. In both cases the specimens were pinned with micropins from the underside between the second pair of legs. Usually, it was preferred not to pierce the scutellum, avoiding possible breakage. The specimens were placed in the groove of a specially-built spreading board (Bayendi Loudit et al. 2014), and their right wings were spread. After drying (twice for ten minutes in the oven at $50^{\circ} \mathrm{C}$ ) the micropins were better joined to the thorax by means of water-soluble glue; afterwards, the specimens were mounted on a plastozote cube. This preparation, very unusual in the Membracidae collections and described in Bayendi Loudit et al. (2014), allows the examiner to quickly observe the wing pattern and the lateral and dorsal abdomen morphology. The genitalia were not examined in order to preserve the limited number of collected specimens and also because the body's external characters are distinctive enough.

The investigated habitats ranged from secondary forest to deforested lands and crops around the equator. Here, both Gabon and Equatorial Guinea present in very general terms two dry seasons (DecemberJanuary, and May-August) and two rainy seasons (February-April, and September-November) with many exceptions. Our surveys cover a period during the rainy seasons. 
With regard to the Gabonese locations, the forests there presents transitional characteristics between the Western Congolese forest with Atlantic influences and the true Congolese forest, without a clear line of demarcation (Vande Weghe 2010).

The Guinean location (the village of Mossumu, near Nyefang) presents a mosaic of secondary forest, from quite degraded to well preserved.

Morphological terms are from Funkhouser (1950), Capener (1962, 1968), Deitz (1975), Dietrich et al. (2001) and Wallace \& Deitz (2004).

In the species descriptions the following conventions are used: vertex width is the distance between the compound eyes measured along the centro-ocular line; vertex height is the distance measured from the ventral margin to the upper margin, perpendicular to the centro-ocular line (see Bayendi Loudit et al. 2014: fig. 4). The total length of the body is measured laterally from the head to the apex of the abdomen; the pronotal length is measured from the anterior profile of the pronotum to the apex of the posterior process; the tegminal length is measured from the costa base to the apex of the spread wing.

\section{Abbreviations \\ $1 / \mathrm{w}=$ length/width ratio \\ $\mathrm{w} / \mathrm{h}=$ width/height ratio}

Museum acronyms (follow Evenhuis 2020)

$\begin{array}{ll}\text { ANPN } & \text { Agence nationale des Parcs nationaux (Gabon) } \\ \text { CENAREST } & =\text { Centre national de la Recherche scientifique et technologique, Libreville, Gabon } \\ \text { IRAF } & =\text { Institut de Recherches agronomiques et forestières, Libreville, Gabon } \\ \text { IRET } & =\text { Institut de Recherche en Écologie tropicale, Libreville, Gabon } \\ \text { MNHN } & =\text { Muséum national d'histoire naturelle, Paris, France } \\ \text { MSNS } & \text { Museo di Storia naturale del Salento (Natural History Museum of the Salento), Italy } \\ \text { RMCA } & =\text { Royal Museum for Central Africa, Tervuren, Belgium }\end{array}$

\section{Results}

Class Insecta Linnaeus, 1758

Order Hemiptera Linnaeus, 1758

Family Membracidae Rafinesque, 1815

Subfamily Centrotinae Amyot \& Serville, 1843

Genus Hamma Buckton, 1905

The description of three proposed new species is here reported. They were discovered in Gabon and Equatorial Guinea by the third author. The following checklist and keys include the new entries since 2014 (Durante \& Susini 2017, plus present data).

\section{Check-list of the species belonging to the genus Hamma}

1. Hamma boulardi Bayendi Loudit, Durante \& Susini, 2014

Hamma boulardi Bayendi Loudit, Durante \& Susini, 2014: 323-346, fig. 9

2. Hamma brevicornis Boulard, 1968

Hamma brevicornis Boulard, 1968: 942-944, figs 3, 10-11

3. Hamma caneparii sp. nov.

4. Hamma capeneri Boulard, 1968

Hamma capeneri Boulard, 1968: 938-941, figs 1, 8, 16 
5. Hamma carlini Bayendi Loudit, Durante \& Susini, 2014

Hamma carlini Bayendi Loudit, Durante \& Susini, 2014: 323-346, fig. 12

6. Hamma cinnameus Boulard, 1969

Hamma cinnameus Boulard, 1969: 106-107, figs 3-5

7. Hamma cupreum Durante \& Susini, 2017

Hamma cupreum Durante \& Susini, 2017: 3-8, fig. 5

8. Hamma fabulosum Boulard, 1968

Hamma fabulosum Boulard, 1968: 945-946, figs 5, 14-15

9. Hamma franciscae Bayendi Loudit, Durante \& Susini, 2014

Hamma franciscae Bayendi Loudit, Durante \& Susini, 2014: 323-346, fig. 14

10. Hamma grahami (Distant, 1916)

Amitrochates grahami Distant, 1916b: 328

Hamma mabirensis China, 1923: 463-465; synonymized by Funkhouser 1927

Hamma grahami (Distant) - Capener 1955: 376

11. Hamma heimi Boulard, 1968

Hamma heimi Boulard, 1968: 944-945, figs 4, 12-13

12. Hamma nigrum sp. nov.

13. Hamma nodosum Buckton, 1905

Hamma nodosum Buckton, 1905: 330, pl 21 fig. 3

Hamma nodosa Buckton, 1905: 330; incorrect subsequent spelling for H. nodosum

14. Hamma pattersoni Distant, 1916

Hamma pattersoni Distant, 1916a: 157-158

15. Hamma pygmaeum Capener, 1972

Hamma pygmaeum Capener, 1972: 50-51, figs 198-200

16. Hamma rectum (Vignon, 1930)

Amitrochates rectus Vignon, 1930: 408-409, fig. 673

Hamma kilossae Dlabola, 1945: 155-156, synonymized by Metcalf \& Wade 1965: 506

Hamma recta - Metcalf \& Wade 1965: 506

Hamma rectum - Capener 1968: 108

Hamma rectum - Boulard, 1968: 946-948 [new description], figs 6-7

17. Hamma robustum Capener, 1971

Hamma robustum Capener, 1971: 28-29, figs 23-25

18. Hamma sandrinei Durante \& Susini, 2017

Hamma sandrinei Durante \& Susini, 2017: 3-8, figs 2-3

19. Hamma simplex Boulard, 1968

Hamma simplex Boulard, 1968: 941-942, figs 2, 9

20. Hamma spinellii sp. nov.

21. Hamma spinosum Capener, 1971

Hamma spinosum Capener, 1971: 25-27, figs 17-19

22. Hamma ugandensis Capener, 1971

Hamma ugandensis Capener, 1971: 27-28, figs 20-22

\section{Key to species of the genus Hamma (updated after Bayendi Loudit et al. 2014)}

1. Posterior pronotal process without terminal spine (Bayendi Loudit et al. 2014: figs 12, 14) .......... 2



2. Pronotum with reddish brown blunt tubercles (Bayendi Loudit et al. 2014: fig. 14)

Hamma franciscae Bayendi Loudit, Durante \& Susini, 2014

- Pronotum with black thorn-like tubercles (Bayendi Loudit et al. 2014: fig. 12)

Hamma carlini Bayendi Loudit, Durante \& Susini, 2014 
3. Suprahumeral horns prominent, ending in a thorn (Bayendi Loudit et al. 2014: fig. 6) ................. 4

- Suprahumeral horns absent or not prominent, apex blunt (Durante \& Susini 2017: fig. 2) ........... 18

4. Posterior pronotal process quite slender in lateral view without evident nodes ............................. 5

- Posterior pronotal process in lateral view with evident nodes ........................................................ 6

5. Suprahumeral horns globose (more clearly visible in frontal view) (Boulard 1969: fig. 3)

Hamma cinnameus Boulard, 1969

- Suprahumeral horns conical

6. Suprahumeral horns very large, posterior process heart-shaped in dorsal view (Boulard 1968: figs 14-15) Hamma fabulosum Boulard, 1968

- Suprahumeral horns smaller, posterior process not heart-shaped in dorsal view 8

7. Pterostigma twice as long as broad (Boulard 1968: figs 8, 16) .......Hamma capeneri Boulard, 1968

- Pterostigma three times as long as broad (Durante \& Susini 2017: fig. 2)

Hamma cupreum Durante \& Susini, 2017

8. Pronotum tuberculate with reddish tubercles (Buckton 1905: pl. 21 fig. 3)

Hamma nodosum Buckton, 1905

- Pronotum smooth or tuberculate with black tubercles

9. Suprahumeral horns upturned (Boulard 1968: figs 10-11) .........Hamma brevicornis Boulard, 1968

- Suprahumeral horns laterad

10. Posterior process with terminal node large and clearly rounded in dorsal view

- Posterior process with terminal node quite slender, not rounded in dorsal view (Capener 1971: fig. 25)

Hamma robustum Capener, 1971

11. Suprahumeral horns about half as long as pronotal width (dorsal view) (Bayendi Loudit et al. 2014: fig. 7)

- Suprahumeral horns about $1 / 4$ to $1 / 3$ as long as pronotal width (dorsal view) (Bayendi Loudit et al. 2014: fig. 9)

12. Posterior process V-shaped in lateral view between second and fourth node (Fig. 1)

- Posterior process straight in lateral view between second and fourth node (Vignon 1930: fig. 673)

Hamma rectum (Vignon, 1930)

13. Thorax entirely black

- Thorax predominantly brown

14. Suprahumeral horns straight in dorsal view

- Suprahumeral horns curved backwards in dorsal view (Boulard 1968: fig. 13)

Hamma heimi Boulard, 1968

15. Pterostigma as long as broad (Distant 1916b: fig. page 328)

Hamma grahami (Distant, 1916)

- Pterostigma about three times as long as broad (Fig. 1) Hamma nigrum sp. nov.

16. Caudal node of the posterior process half the width of the head in dorsal view (Fig. 2)

Hamma spinellii sp. nov.

- Caudal node of the posterior process $2 / 3$ the width of the head in dorsal view (Fig. 3)

Hamma caneparii sp. nov. 
17. Posterior process shorter than the tegmina, suprahumeral horns with short, stout terminal spine (Bayendi Loudit et al. 2014: fig. 9) ..... Hamma boulardi Bayendi Loudit, Durante \& Susini, 2014

- Posterior process as long as the tegmina, suprahumeral horns with slender terminal spine (Capener 1971: figs 17-19) Hamma spinosum Capener, 1971

18. Posterior process in dorsal view with large terminal node

- Posterior process in dorsal view with very small terminal node

19. Posterior process heart-shaped, almost as large as the metopidium in dorsal view (Capener 1971: fig. 22)

Hamma ugandensis Capener, 1971

- Posterior process roundish, about half as large as the metopidium in dorsal view (Durante \& Susini 2017: fig. 2) Hamma sandrinei Durante \& Susini 2017

20. Posterior process slender in lateral view

- Posterior process quite strong in lateral view (Distant 1916a: fig. page 158)

Hamma pattersoni Distant, 1916

21. Flanks of the pronotal helmet and thoracic pleurae covered in white hairs; posterior process with lateral carinae (Boulard 1968: figs 2, 9)

Hamma simplex Boulard, 1968

- No presence of white hairs; posterior process without lateral carinae (Capener 1972: figs 198-200)

Hamma pygmaeum Capener, 1972

The following species are here considered to be part of a well-defined group, characterized by a similar exterior morphology (especially well-pronounced suprahumeral horns; pronotal posterior process with four nodes; third node of the posterior process anchor-shaped in dorsal view; welldeveloped terminal spine on the posterior process; wings with dark pattern). We include also Hamma heimi Boulard, 1968.

\title{
Description of the new species
}

\author{
Hamma nigrum sp. nov. \\ urn:1sid:zoobank.org:act:6A5C5E1E-9D51-41C8-8D1E-75B5C1C458D4
}

Figs 1, 4B, 5B

\section{Diagnosis}

Species belonging to the genus Hamma with the thorax entirely black and pronotum smooth; suprahumeral horns with a laterally pointing thorn; a posterior process with four nodes, V-shaped in lateral view between the second and fourth nodes; last node roundish in dorsal view, ending in a well-developed terminal spine. Pterostigma about three times as long as broad.

\section{Differential diagnosis}

The general black colour clearly distinguishes this species from the following two (i.e., spinellii sp. nov. and caneparii sp. nov.), although not from Hamma heimi. The roughly triangular shape of the supraocular callosity (Fig. 4B) is also diagnostic with respect to all other species in the group.

The anchor-like third node (Fig. 5B) of the posterior process clearly distinguishes it from all other species in the group, being rhomboidal in dorsal view, whereas it is roughly circular in heimi, and truly anchor-like in spinellii sp. nov. and in caneparii sp. nov. 
Other diagnostic characters with respect to spinellii sp. nov. and caneparii sp. nov. include:

- upper margin of the head (Fig. 4B) roughly circular (roughly square in spinellii sp. nov. and caneparii sp. nov.);

- metopidium (Fig. 4B) smooth (tuberculate in spinellii sp. nov. and caneparii sp. nov.);

- suprahumeral horns (Fig. 4B) with a robust thorn slightly curving dorsally in frontal view (straight in spinellii sp. nov. and caneparii sp. nov.);

- pterostigma (Fig. 5B) diagnostic only with respect to caneparii sp. nov.: 1/w ratio 2.95 in nigrum sp. nov. (mean value); 2.4 in caneparii sp. nov.

Diagnostic characters with respect to heimi include:

- upper margin of the head more arcuate than in heimi;

- punctation on the pronotum finer than in heimi;

- first (proximal) node of the posterior process roughly circular in lateral view, dome-shaped in heimi.

\section{Etymology}

The species takes its name from the Latin adjective 'nigrus', meaning 'black', in the neuter form in accordance with the grammatical gender.

\section{Material examined}

\section{Holotype}

GABON • क; Ogooué Ivindo, Mont Sassamongo, Batouala; 1 Dec. 2012; A. Susini leg.; MSNS.

\section{Paratypes}

EQUATORIAL GUINEA • 1 q; Nyefang, Mossumu; 5 Oct. 2015; A. Susini leg.; MSNS • 1 q; same collection data as for preceding; coll. Susini.

\section{Description}

MeAsurements. Holotype total length: $5.2 \mathrm{~mm}$, average total length: $4.5 \mathrm{~mm}$; holotype pronotal length: $5 \mathrm{~mm}$; average pronotal length: $4.7 \mathrm{~mm}$; holotype tegminal length: $4.2 \mathrm{~mm}$, average tegminal length: $4.2 \mathrm{~mm}$.

HEAD. Brilliant black, convex, punctate, with very small and sparse setae; vertex almost twice as wide as high; shallow concavity between the ocelli; upper margin arcuate, rounded, slightly sinuate; ventral margin $\mathrm{W}$-shaped with the lower parts not very pronounced; ocelli clearly above the centro-ocular line. Frontoclypeus pear-shaped, lateral lobes completely fused to frontoclypeus with margins barely distinguishable; rostrum dark brown; antennae light brown.

Pronotum. Brilliant black, punctate, almost completely naked; metopidium smooth, almost twice as wide as high, median carina percurrent, unpunctate, straight until the base of the posterior process and subsequently sinuate, supraocular callosities barely noticeable, small and unpunctate, roughly triangular; humeral angles prominent and blunt; suprahumeral horns well developed, with a tower-shaped base (width/height ratio: 1.48), slightly tuberculate, sometimes with dorsal tip reddish-brown, with a robust brown thorn projecting outwards and curving upwards slightly in frontal view. Posterior process brilliant black, punctate, emerging posteriorly from the pronotum and continuously from the posterior margin; sinuate in lateral view, with four nodes, the first of which (proximal) almost spherical; second node small, dome-shaped in lateral view (flattened in dorsal view) with four to eight small spines dorsally; third node anchor-like in dorsal view with one to three spines at the end of the lateral arms; fourth node subspherical, almost twice as big as the first, with many spines and a robust terminal spine at the caudal end; dorsal and ventral carinae discontinuous, black, in some parts tending to brown. A few spines 


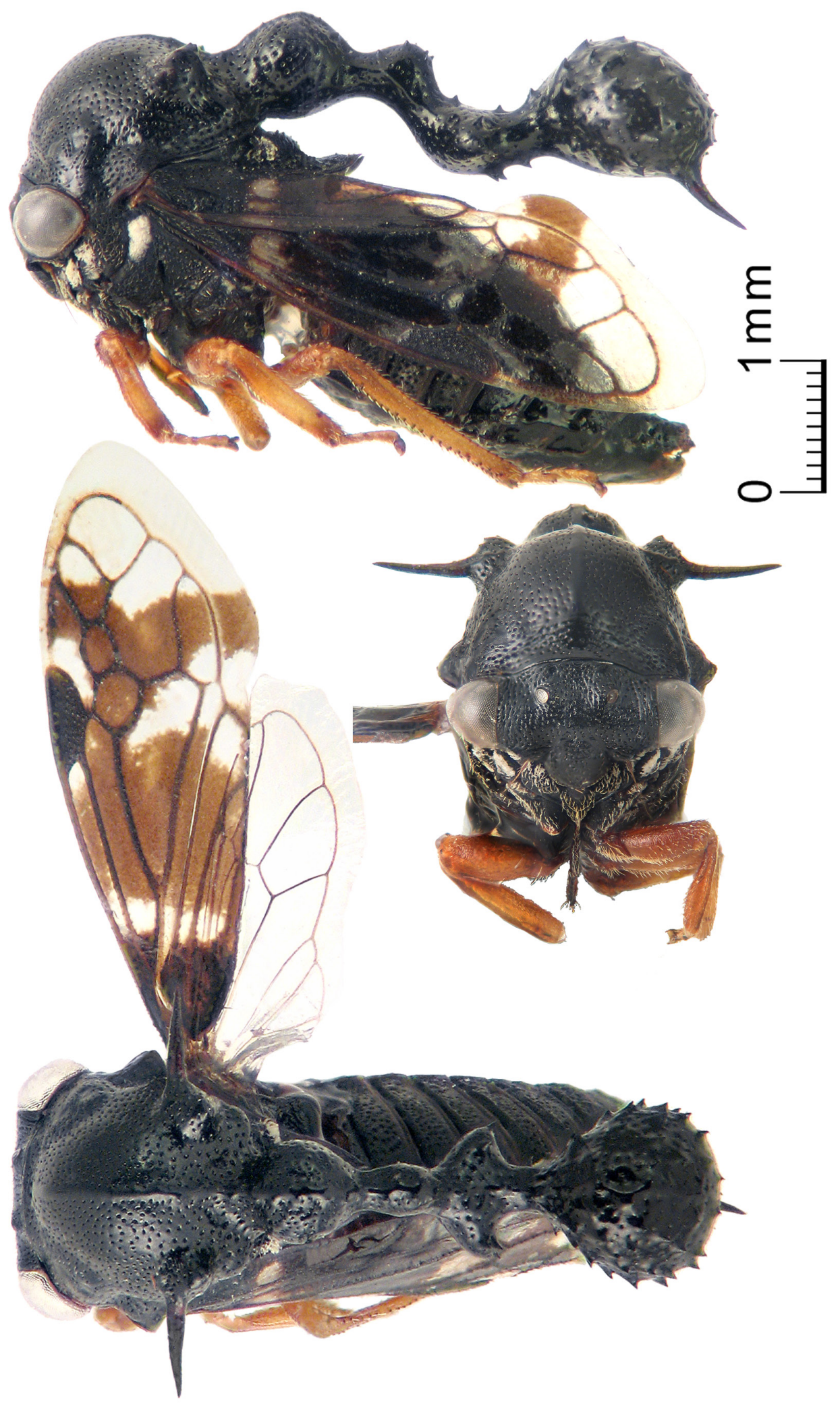

Fig. 1. Hamma nigrum sp. nov., holotype, $q$, Gabon, Ogouè Ivindo, Batuala, 1 Dec. 2012, A. Susini leg. (MSNS). 
dorsally and ventrally along the trunk of the posterior process between the third and fourth nodes. Each spine bears a very thin light apical seta.

Scutellum (Fig. 5). Entirely black, punctate, with the base longer than the height, emarginate, with scutellar apices acute with a few translucent setae; base swollen except for the corners, with one ogival tubercle on each side of the swelling, each tubercle with a tuft of small whitish setae.

Forewing. Almost three times as long as wide (1/w ratio 2.94, mean value), hyaline; basally sclerotized, punctate, dark brown-black in colour. Pterostigma sub-triangular with very rounded corners, blackish in colour; venation black to brown; a large sub-pentagonal brown patch extending from costa to inner margin in the median area; a Y-shaped brown patch extending from costa to anal angle, connected with the previous patch at the level of the second discoidal cell.

LEGS. Ochreous yellow, praetarsi brown.

AвDOMEn. Urites black with punctation (in one specimen with white suffusion), and thin brown caudal border.

Hamma spinellii sp. nov. urn:1sid:zoobank.org:act:C19025BA-2C70-4CD0-BF61-68ED3716A5E0

Figs 2, 4C, 5C

\section{Diagnosis}

Species belonging to the genus Hamma with thorax eminently brown, pronotum smooth and metopidium not densely tuberculate; suprahumeral horns with a laterally pointing thorn; a posterior process with four nodes, V-shaped in lateral view between the second and fourth nodes; last node roundish in dorsal view, ending in a well-developed terminal spine. Pterostigma almost three times longer than broad.

\section{Differential diagnosis}

The general light brown colour is diagnostic, heimi and nigrum sp. nov. being black, and caneparii sp. nov. having a mosaic of russet brown and black.

Other diagnostic characters with respect to caneparii sp. nov. are:

- the similarity of the width and height of the basal element of the suprahumeral horns (frontal view) (Fig. 4C): in spinellii sp. nov. the $\mathrm{w} / \mathrm{h}$ ratio is 1 ; in caneparii sp. nov. the $\mathrm{w} / \mathrm{h}$ ratio is 0.66 ;

- caudal node of the posterior process half the width of the head in spinellii sp. nov.; ${ }^{2 / 3}$ the width in caneparii sp. nov. (dorsal view);

- anchor-like third node (Fig. 5C) thinner than in caneparii sp. nov. (dorsal view);

- length of the posterior process clearly exceeding abdominal length in spinellii sp. nov.; not exceeding the abdominal terminalia in caneparii sp. nov. (lateral view);

- pterostigma (Fig. 5C) longer in spinellii sp. nov.: 1/w ratio 3.4 in spinellii sp. nov.; 2.4 in caneparii sp. nov.

Other diagnostic characters with respect to heimi and nigrum sp. nov. include:

- upper margin of the head roughly square (Fig. 4C);

- metopidium (Fig. 4C) tuberculate;

- suprahumeral horns (Fig. 4C) with a robust straight thorn, not curving upwards in frontal view;

- anchor-like third node (Fig. 5C) posteriorly prolonged (dorsal view); rhomboidal or roughly circular in nigrum sp. nov. and heimi. 


\section{Etymology}

The species is dedicated to Dr Matteo Spinelli, Milano.

\section{Material examined}

\section{Holotype}

GABON • O; Ogooué Ivindo, Mont Sassamongo, Batouala; 30 Nov. 2012; A. Susini leg.; MSNS.

\section{Description}

Measurements. Holotype total length: $3.8 \mathrm{~mm}$; pronotal length: $4.4 \mathrm{~mm}$; tegminal length: $4.3 \mathrm{~mm}$.

HEAD. Black with brown suffusion along the margins and at the centre, convex, punctate, with small white setae; vertex width one and a half times the height; shallow concavity between the ocelli; carina present; upper margin arcuate but roughly square with two evident corners, one directly above each ocellus; ventral margin W-shaped with the lower parts not very pronounced; ocelli slightly above the centro-ocular line. Frontoclypeus pear-shaped, lateral lobes completely fused to frontoclypeus with margins barely distinguishable; rostrum and antennae light brown.

Pronotum. Light brown with one triangular black patch on the metopidium on each side of the carina, punctate, almost completely naked; metopidium tuberculate in its dorsal region, twice as wide as high, median carina percurrent, unpunctate, straight, with some swelling, supraocular callosities bean-like, slightly or not at all punctate, with a small club-shaped darker formation inside them, shallow and very finely punctate; humeral angles prominent and blunt; suprahumeral horns well developed, with a tower-shaped base, tuberculate, with a robust brown and black-tipped thorn pointing laterally? Posterior process light brown, punctate, emerging posteriorly from the pronotum and continuously from the posterior margin; sinuate in lateral view, with four nodes, the first of which (proximal) almost spherical; second node small, dome-shaped in lateral view (flattened in dorsal view) with seven-eight small spines latero-dorsally; third node anchor-like in dorsal view with one (left) or two (right) small spines at the end of the lateral arms; fourth node subspherical, almost one and a half times larger than the first, with many spines and a robust terminal spine at the caudal end; dorsal and ventral carinae continuous, of the same colour. A few spines along the dorsal carina, and dorsally and ventrally along the trunk of the posterior process between the third and fourth nodes. Each spine bears a very thin light apical seta.

Scutellum (Fig. 5). Entirely brown, punctate, with the base longer than the height, emarginate with scutellar apices acute with a few translucent setae; base with a triangular swelling except at the corners; lateral corners of the swelling with a tuft of small shiny ochraceous setae.

ForEwING. Length about two and a half times width (1/w ratio 2.56 ), hyaline; basally sclerotized, punctate, grey-brown in colour with three to four brown stripes distally. Pterostigma sub-triangular with very rounded corners, blackish in colour; venation grey-brown; large brown shaded trapezoidal patch extending from costa to inner margin in the median area; I-shaped patch extending from costa to anal angle with light grey-brown anterior half and dark grey-brown posterior half.

LEGS. Ochreous yellow, praetarsi brown.

ABDOMEN. Tergites grey-brown with black punctation and lighter caudal borders; sternites brown, as are the borders, and covered in translucent setae. 


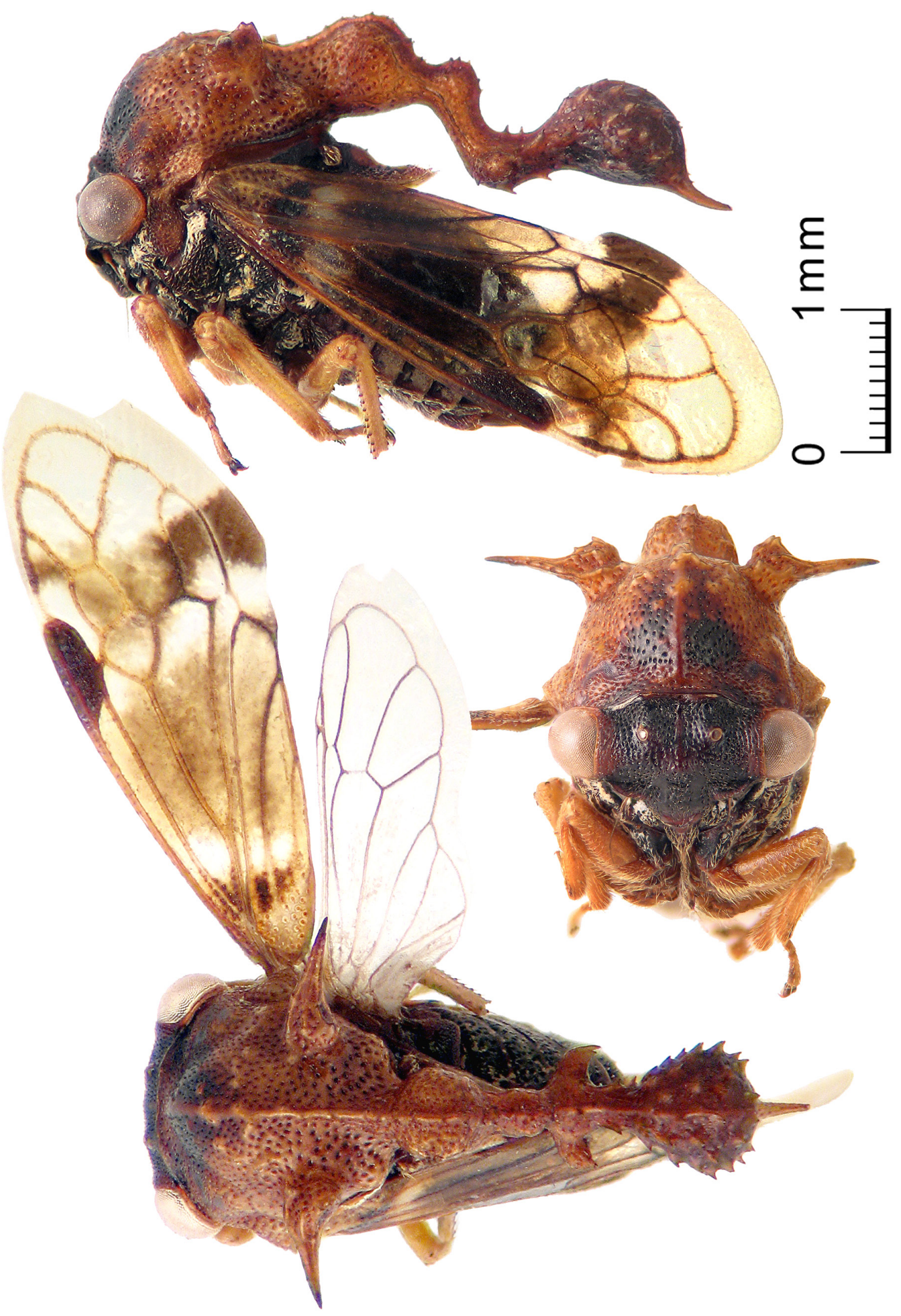

Fig. 2. Hamma spinellii sp. nov., holotype,, , Gabon, Ogouè Ivindo, Mont Sassamongou, Batouala, 30 Nov. 2012, A. Susini leg. (MSNS). 


\section{Hamma caneparii sp. nov. urn:lsid:zoobank.org:act:CC05B142-B36F-4449-B12D-DE869B08470F}

Figs 3, 4D, 5D

\section{Diagnosis}

Species belonging to the genus Hamma with thorax a mosaic of russet brown and black, pronotum smooth and metopidium not densely tuberculate; suprahumeral horns with a laterally pointing thorn; a posterior process with four nodes, V-shaped in lateral view between the second and fourth nodes; last node roundish in dorsal view, ending in a well-developed terminal spine. Pterostigma twice as long as broad.

\section{Differential diagnosis}

The general colour (a mosaic of russet brown and black) is diagnostic, heimi and nigrum sp. nov. being black, and spinellii $\mathrm{n}$. sp being light brown.

Other diagnostic characters with respect to spinellii sp. nov. are:

- the narrow width relative to height of the basal element of the suprahumeral horns (frontal view) (Fig. 4D): in caneparii sp. nov. the $\mathrm{w} / \mathrm{h}$ ratio is 0.66 ; in spinellii sp. nov. the $\mathrm{w} / \mathrm{h}$ ratio is 1 ;

- caudal node of the posterior process $2 / 3$ of the head width in caneparii sp. nov.; half the head width in spinellii sp. nov. (dorsal view);

- anchor-like third node (Fig. 5D) broader than in spinellii sp. nov. (dorsal view);

- length of the posterior process not exceeding the abdominal terminalia in caneparii sp. nov.; clearly exceeding abdominal length in spinellii sp. nov. (lateral view);

- pterostigma (Fig. 5D) larger in caneparii sp. nov.: 1/w ratio 2.4 in caneparii sp. nov.; 3.4 in spinellii sp. nov.

Other diagnostic characters with respect to heimi and nigrum sp. nov. are:

- upper margin of the head (Fig. 4D) roughly square;

- metopidium (Fig. 4D) tuberculate;

- suprahumeral horns (Fig. 4D) with a robust straight thorn, not curving upwards in frontal view;

- anchor-like third node posteriorly prolonged; rhomboidal or roughly circular in nigrum sp. nov. and heimi.

\section{Etymology}

The species is dedicated to our friend Claudio Canepari, Milano, a specialist in Coccinellidae.

\section{Material examined}

Holotype

GABON • P; Ogooué Lolo, Inzambò (Iboundji); 0.1 ${ }^{\circ} 6^{\prime} 21.7^{\prime \prime}$ S, 0.11 ${ }^{\circ} 51^{\prime} 17.8^{\prime \prime}$ E; 427 m a.s.1.; 24 Nov. 2012; A. Susini leg.; MSNS.

\section{Description}

Measurements. Holotype total length: $4.6 \mathrm{~mm}$; pronotal length: $4.6 \mathrm{~mm}$; tegminal length: $4.1 \mathrm{~mm}$.

HEAD. Entirely black, convex, punctate; vertex almost twice as wide as high; carina not distinguishable; shallow concavity medially above the ocelli; upper margin sinuate; ventral margin W-shaped with lower parts not very pronounced; ocelli slightly above the centro-ocular line. Frontoclypeus russet and pear- 


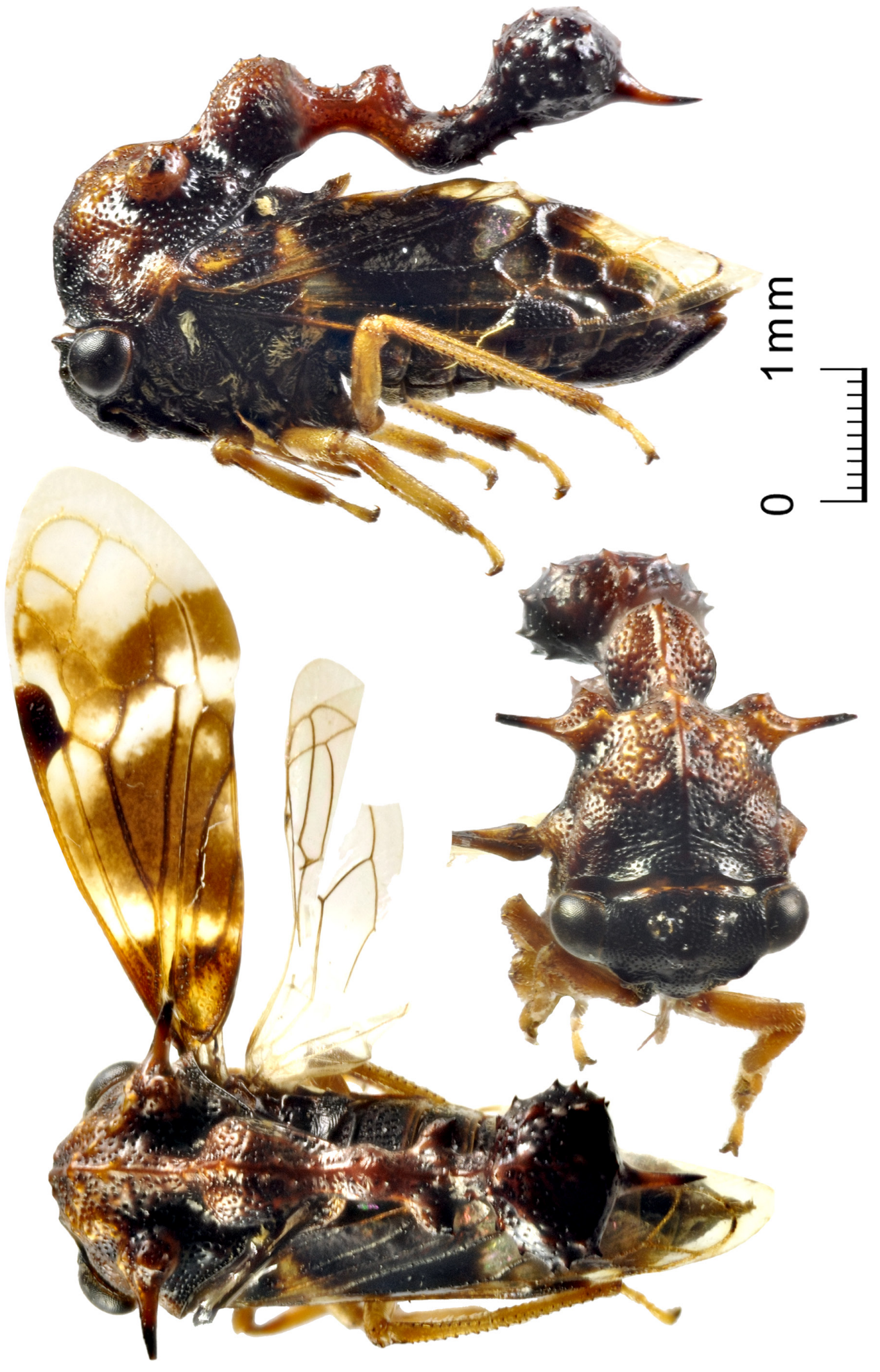

Fig. 3. Hamma caneparii sp. nov., holotype, + , Gabon, Ogoouè Lolo, Inzambò (Iboundji), m 427, $0.1^{\circ} 6^{\prime} 21.7^{\prime \prime}$ S, $0.11^{\circ} 51^{\prime} 17.8^{\prime \prime}$ E, 24 Nov. 2012, A. Susini leg. (MSNS). 


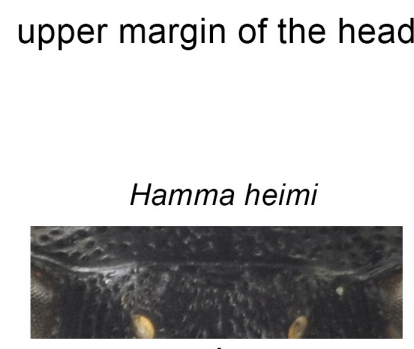

A

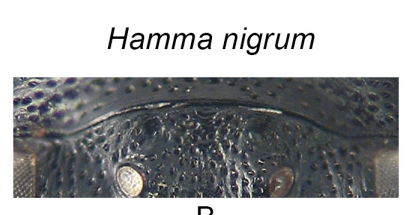

B

Hamma spinellii

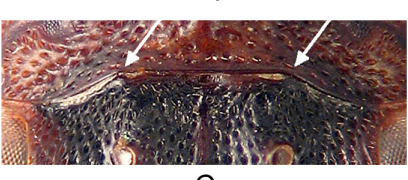

C

Hamma caneparii
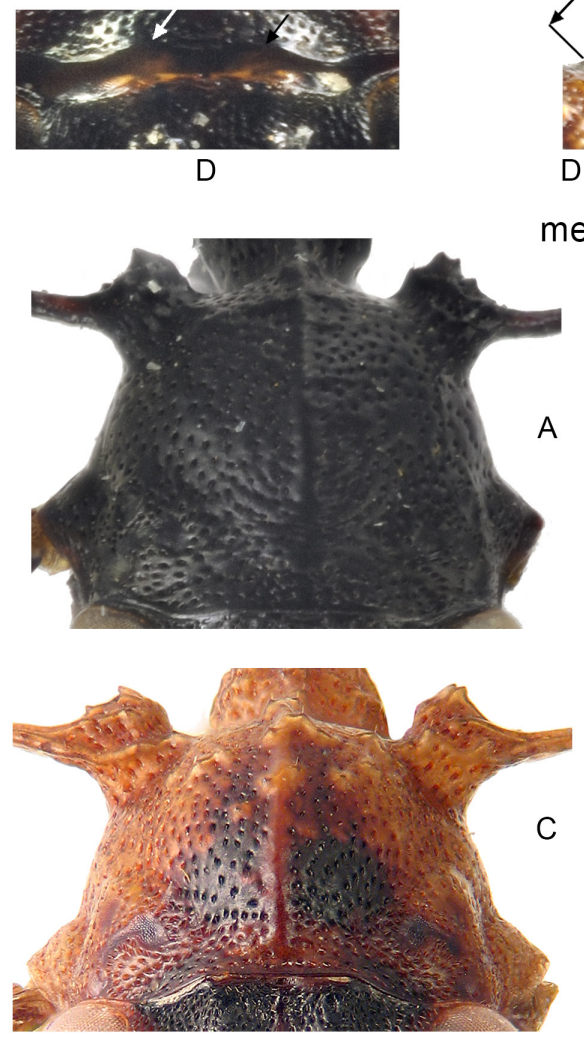

suprahumeral horn



A
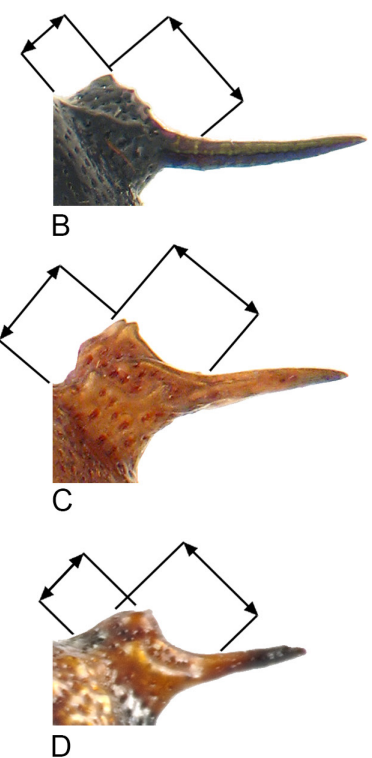

metopidium supraocular callosity



A

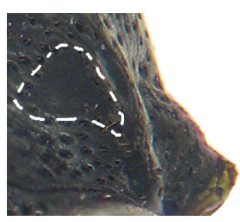

B
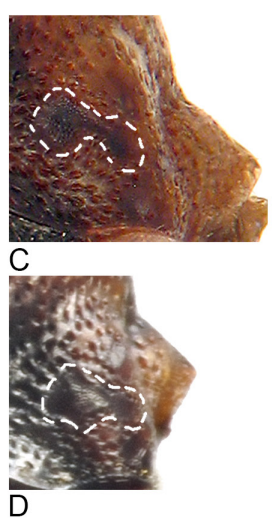

$\bar{D}$
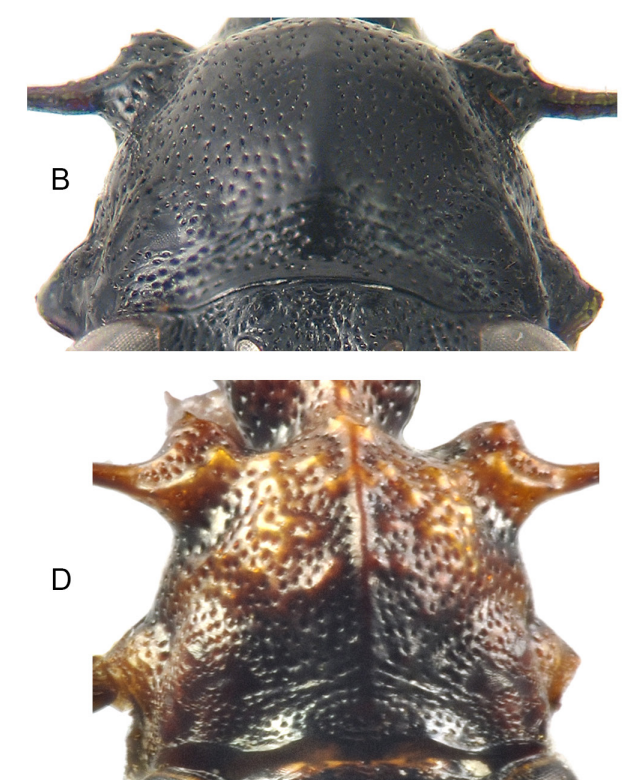

Fig. 4. Morphology. Left suprahumeral horn and left supraocular callosity, frontal view. A. Hamma heimi Boulard, 1968. B. Hamma nigrum sp. nov. C. Hamma spinellii sp. nov. D. Hamma caneparii sp. nov. Figures are not to scale. 
shaped, lateral lobes completely fused to frontoclypeus with margins not distinguishable; rostrum and antennae ochraceous.

Pronotum. Mosaic of russet brown patches with one triangular black area at the base of the metopidium and black areas behind the suprahumeral horns; punctate, naked; ochraceous tuberculate areas at the dorsal border of the metopidium; metopidium one and a half times wider than high, median carina percurrent and unpunctate, straight; elongated supraocular callosities, slightly arcuate, not punctate; humeral angles prominent and blunt; suprahumeral horns well developed, with a tower-shaped base (shorter than in spinellii sp. nov.), tuberculate, with a robust brown, black-tipped thorn pointing outwards. Posterior process patchy, black and russet in colour, punctate, emerging posteriorly from the pronotum and continuously from the posterior margin; sinuate in lateral view, with four nodes, the first of which (proximal) almost spherical, elongated posteriorly in dorsal view; second node small, dome-shaped in lateral view (flattened in dorsal view) with four small dorsal spines; third node anchor-like in dorsal view with two (left) or one (right) small spines at the end of the lateral arms; fourth node subspherical, slightly larger than the first, with many spines and a strong terminal spine at the caudal end; dorsal and ventral carinae continuous, of the same colour. A few spines along the dorsal carina and dorsally and ventrally along the trunk of the posterior process between the third and fourth nodes, some of which bearing a very thin light apical seta.

Scutellum (Fig. 5). Same colour as the pronotum, punctate, with the base longer than the height, emarginate with scutellar apices light, acute with a few translucent setae; base with a triangular swelling except at the corners; lateral corners of the swelling with a tuft of small brilliant whitish setae.

Forewing. About two and a half times as long as wide (1/w ratio 2.57), hyaline; basally sclerotized, punctate, amber and brown in colour. Pterostigma trapezoidal with rounded corners, dark brown in colour; venation amber except for the median, cubital and anal veins in the median area, which are brown; large brown shaded trapezoidal patch extending from costa to inner margin in the median area; S-shaped patch extending from costa to anal angle with light grey-brown anterior half and brown posterior half. Presence in the right forewing of a small supplementary discoidal cell between the second apical cell and the first discoidal cell.

LEGS. Ochreous yellow, praetarsi brown.

AвDOMEn. Tergites black and brown with punctation and lighter caudal borders; sternites brown with borders of the same colour covered by translucent setae.

\section{Discussion}

This third paper on the genus Hamma in Gabon raises the number of known species to 22 in Africa as a whole and to 12 in Gabon alone. Regarding the latter, it should be emphasized that 8 new species have been described since 2014, based on collections made every year from 2010 until 2019, with few specimens collected for each species. This observation coincides with many others made by the authors regarding other orders of Insects, such as Coleoptera, Lepidoptera, Orthoptera and so on, and suggests that Gabon is a very significant centre of endemism. In quite a few cases, many specimens belonging to a small number of species are collected, whereas other species are represented by few specimens or only one, collected during several field trips over ten years. This is the case, for instance, of the Afrotropical genus Tumicla Wallengren, 1863 (Lepidoptera), unrecorded in Gabon until now, and recently discovered together with eight as-yet undescribed species, all of which are represented by very few specimens (Durante \& Apinda Legnouo 2020). The same trend has been observed in Membracidae genera, based on a preliminary classification into different species. This indicates that the vast majority of species from tropical and equatorial regions described in the past two centuries are in fact composed of a small 
pterostigma

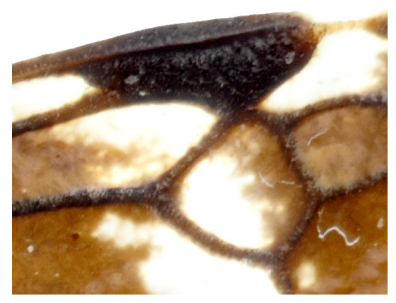

A



C

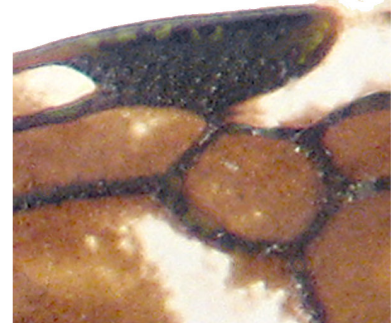

B

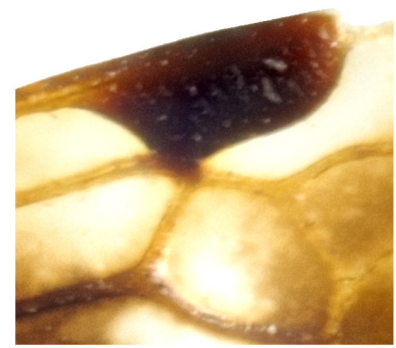

D



A

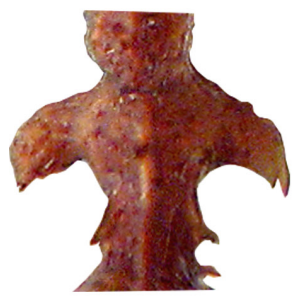

C third node



B

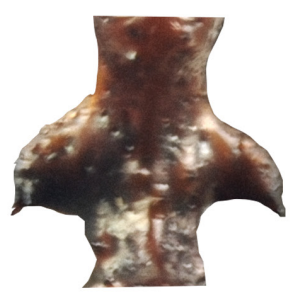

D

scutellum

A



C

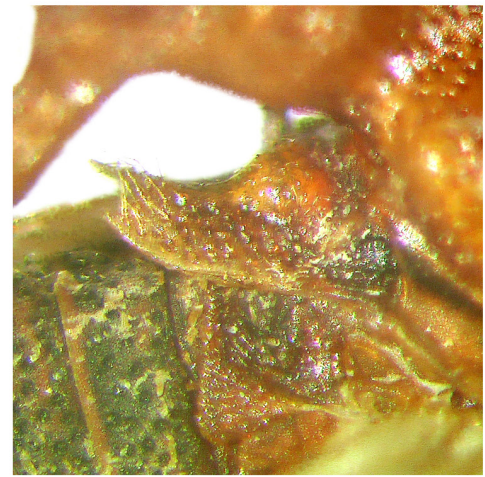

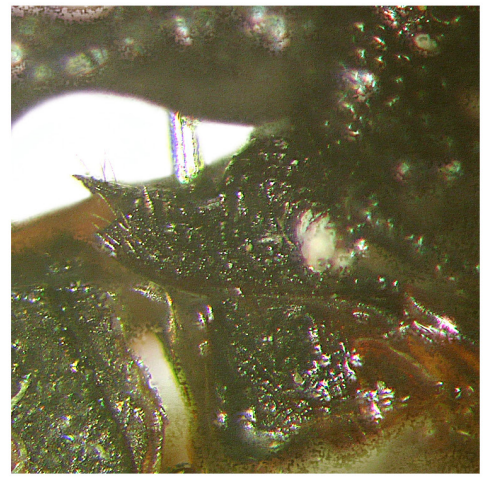

B



Fig. 5. Morphology. Pterostigma of right wing in dorsal view; third node of the posterior process in dorsal view; scutellum in lateral right view. A. Hamma heimi Boulard, 1968. B. Hamma nigrum sp. nov. C. Hamma spinellii sp. nov. D. Hamma caneparii sp. nov. Figures are not to scale. 
number of individuals spread over such a large range that it is extremely difficult to collect them in large numbers. On the contrary, until now the most accepted conclusion has been that the small numbers are due to the inadequacy of research and collection methods. Although the latter view undoubtedly has merit, due to the objective difficulties in terms of logistics and obtaining collection permits in tropical countries, the authors stress that many species are indeed composed of very low density populations with respect to the high complexity of tropical environments and the wideness of their range (as shown by the relation between population density and trap collection of insects - see Petrovskii et al. 2012). They also argue that many species are probably composed of very few populations or only one, confined to a small area. The latter observation is supported by the fact that specimens of certain species are often found in only one specific location, even when the area around it is well explored (Durante pers. obs.).

The case of $H$. nigrum sp. nov. (its disjunct distribution) could be thought of as an example of a species that once had a large distribution that was subsequently fragmented and reduced, or, alternatively, as a concrete case of shallow investigation in its range. The third hypothesis is that the Guinean specimens are morphologically identical to the Gabonese ones (a case of convergence), but they belong to a separate species, and this would confirm the punctiform (single-area) distributional hypothesis. The genitalia of the H. nigrum sp. nov. specimens were not dissected due to the scarcity of the material.

\section{Acknowledgements}

Permission to visit and collect in Gabonese parks was obtained by means of an international agreement between the CENAREST and the MSNS in order to implement common research projects. The contributions of the IRAF and the IRET were fundamental in helping with facilities in the Ipassa Research Station, and the authors thank the following for their important roles: Daniel Franck Idiata (former Commissaire Général of the CENAREST, Gabon), Auguste Ndoutoume-Ndong (former Director of the IRAF), Alfred Ngomanda (former Director of the IRET), Joseph Vivien Okouyi Okouyi (former Conservator of the Ivindo National Park) and Aurélie Flore Koumba Pambo (former secretary of the Scientific Research Authorisation Board of CENAREST). Special thanks to the Agence Nationale des Parcs Nationaux (Gabon) and to the Direction de la Faune et de la Chasse of the Ministère des Eaux et Forêts of Gabon in Libreville for export permits. The authors are indebted to Michele Zilioli (Museo civico di Storia naturale di Milano), who drew Figs 1 and 2; and they thank two anonymous referees for their valuable comments. The present paper (marked MSNS-GE8) was written as part of the MSNS's Gabonese Entomology research program (the previous paper being Durante \& Apinda-Legnouo 2020, marked MSNS-GE7).

\section{References}

Bayendi Loudit S.M., Durante A. \& Susini A. 2014. Membracidae of Gabon: the genus Hamma Buckton, 1905 (Hemiptera: Auchenorrhyncha) with description of three new species. Zootaxa 3838 (3): 323-346. https://doi.org/10.11646/zootaxa.3838.3.5

Boulard M. 1968. Description de cinq Membracides nouveaux du genre Hamma accompagnée de précisions sur H. rectum. Annales de la Société entomologique de France (n.s.) 4 (4): 937-950.

Boulard M. 1969. Note sur Hamma nodosum (Buckton) et description d'une espèce nouvelle de Membracidae appartenant au même genre. Cahiers la Maboké 7 (2): 103-107.

Buckton G.D. 1905. Observation on some undescribed or little known species of Hemiptera-Homoptera of the family Membracidae. Transactions of the Linnean Society of London 9 (2): 329-338.

https://doi.org/10.1111/j.1096-3642.1905.tb00457.x 
Capener A.L. 1955. Homoptera Membracidae. Contribution à l'étude de la faune entomologique du Ruanda-Urundi (Mission P. Basilewsky 1953). Annales du Musée royal du Congo belge, Série in $8 v o$. Zoology 36: 368-389.

Capener A.L. 1962. The taxonomy of the African Membracidae. Part I. The Oxyrhachinae. Entomology Memoir, Department of Agricultural Technical Service, Republic of South Africa 6: 1-164.

Capener A.L. 1968. The Taxonomy of the African Membracidae: part 2, the Centrotinae. Entomology Memoir, Department of Agricultural Technical Service, Republic of South Africa 17: 1-124.

Capener A.L. 1971. New African Membracidae (Hemiptera Homoptera). Journal of the Entomological Society of South Africa 34 (1): 17-31.

Capener A.L. 1972. New genera and species of African Membracidae (Hemiptera Homoptera). Entomology Memoir, Department of Agricultural Technical Service, Republic of South Africa 24: 1-52.

China W.E. 1923. A new species of Membracidae (Centrotinae) from Uganda. The Annals and Magazine of Natural History, Series 9 11: 463-465. https://doi.org/10.1080/00222932308632871

Deitz L.L. 1975. Classification of the Higher Categories of the New World Treehoppers (Homoptera, Membracidae). North Carolina Agricultural Experiment Station Technical Bulletin, 225.

Dietrich C.H., McKamey S.H. \& Deitz L.L. 2001. Morphology-based phylogeny of the treehopper family Membracidae (Hemiptera, Cicadomorpha, Membracoidea). Systematic Entomology 26: 213239. https://doi.org/10.1046/j.1365-3113.2001.00140.x

Distant W.L. 1916a. Rhynchotal notes 58. Homoptera. Fam. Membracidae. The Annals and Magazine of Natural History, Series 8 17: 149-159. https://doi.org/10.1080/00222931608693759

Distant W. L. 1916b. Rhynchotal notes 59. Homoptera. Fam. Membracidae. The Annals and Magazine of Natural History, Series 8 17: 313-330. https://doi.org/10.1080/00222931608693791

Dlabola J. 1945. New species of the Family Membracidae from East Africa (Homoptera). Acta Entomologica Musei Nationalis Pragae 23: 155-157.

Durante A. \& Apinda-Legnouo E.A. 2020. Report on species of the genus Tumicla Wallengren, 1863 in Gabon (Lepidoptera: Erebidae: Arctiinae: Lithosiini). Zootaxa 4868 (1): 90-116.

https://doi.org/10.11646/zootaxa.4868.1.5

Durante A. \& Susini A. 2017. Nuove specie del genere Hamma Buckton, 1905 (Hemiptera: Auchenorrhyncha) in Gabon. Atti della Società italiana di Scienze naturali del Museo civico di Storia naturale di Milano 4 (1): 3-8.

Evenhuis N.L. 2020. The Insect and Spider Collections of the World website. Available from http://hbs.bishopmuseum.org/codens/ [accesed 17 Jun. 2020].

Funkhouser W.D. 1927. General Catalogue of the Hemiptera, Fasc. 1. Membracidae. Smith College, Northampton, MA. https://doi.org/10.5962/bhl.title.6822

Funkhouser W.D. 1950. Homoptera, Fam. Membracidae. In: Witsman P. (ed.) Genera Insectorum 208: 1-383. Louis Desmet-Verteneuil, Bruxelles.

Goding F.W. 1932. The Membracidae of Africa. Journal of the New York Entomological Society 40 (2): $205-237$.

Kopp D.D. \& Yonke T.R. 1973. The treehoppers of Missouri: Part 1. Subfamilies Centrotinae, Hoplophorioninae, and Membracinae (Homoptera: Membracidae). Journal of the Kansas Entomological Society 46: 42-64. 
McKamey S.H. 1998. Taxonomic Catalogue of the Membracoidea (exclusive of Leafhoppers). Second Supplement to Fascicle 1 - Membracidae of the General Catalogue of the Hemiptera. Memoirs of the American Entomological Institute vol. 60, Gainesville, FL.

Metcalf Z.P. \& Wade V. 1965. General Catalogue of the Homoptera. A Supplement to Fascicle I. Membracidae of the General Catalogue of Hemiptera. Membracoidea. In two Sections. North Carolina State University, Raleigh, NC.

Petrovskii S., Bearup D., Ahmed D.A. \& Blackshaw R. 2012. Estimating insect population density from trap counts. Ecological Complexity 10: 69-82. https://doi.org/10.1016/j.ecocom.2011.10.002

Stål C. 1866. Hemiptera Africana. Vol. IV. Ex Officina Norstedtiana, Stockholm [Holmiae].

Vande Weghe G.R. 2010. Papillons du Gabon. Wildlife Conservation Society, Libreville.

Vignon P. 1930. Introduction à la Biologie Expérimentale. In: Encyclopédie biologique 8: 408-409. Lechevalier, Paris.

Wallace M.S. \& Deitz L.L. 2004. Phylogeny and Systematic of the Treehopper Subfamily Centrotinae (Hemiptera, Membracidae). Memoirs on Entomology, International, 19, Associated Publishers, Gainesville, FL.

Manuscript received: 3 July 2020

Manuscript accepted: 3 March 2021

Published on: 6 May 2021

Topic editor: Nesrine Akkari

Section editor: Christopher H. Dietrich

Desk editor: Pepe Fernández

Printed versions of all papers are also deposited in the libraries of the institutes that are members of the EJT consortium: Muséum national d'histoire naturelle, Paris, France; Meise Botanic Garden, Belgium; Royal Museum for Central Africa, Tervuren, Belgium; Royal Belgian Institute of Natural Sciences, Brussels, Belgium; Natural History Museum of Denmark, Copenhagen, Denmark; Naturalis Biodiversity Center, Leiden, the Netherlands; Museo Nacional de Ciencias Naturales-CSIC, Madrid, Spain; Real Jardín Botánico de Madrid CSIC, Spain; Zoological Research Museum Alexander Koenig, Bonn, Germany; National Museum, Prague, Czech Republic. 